\title{
INFLUENCE OF NANO-SIZED COBALT OXIDE ADDITIONS ON THE STRUCTURAL AND ELECTRICAL PROPERTIES OF NICKEL-MANGANITE-BASED NTC THERMISTORS
}

\author{
VPLIV DODATKA NANODELCEV KOBALTOVEGA OKSIDA NA \\ ZGRADBO IN ELEKTRIČNE LASTNOSTI NTC TERMISTORJEV \\ NA OSNOVI NIKLJEVEGA MANGANITA
}

\author{
Gökhan Hardal, Berat Yüksel Price \\ Istanbul University, Engineering Faculty, Metallurgical and Materials Engineering Department, Avc1lar, Istanbul, Turkey \\ berat@istanbul.edu.tr
}

Prejem rokopisa - received: 2015-07-15; sprejem za objavo - accepted for publication: 2015-12-15

doi:10.17222/mit.2015.228

\begin{abstract}
The structural and electrical properties of $\mathrm{NiMn}_{2} \mathrm{O}_{4}$ and $\mathrm{Ni}_{0.5} \mathrm{Co}_{\mathrm{x}} \mathrm{Mn}_{2.5-\mathrm{x}} \mathrm{O}_{4}$ (where $x=0.5,0.8$ and 1.1) NTC thermistors have been investigated. The samples, prepared by conventional ceramic processing techniques, were calcinated at $900{ }^{\circ} \mathrm{C}$ for $2 \mathrm{~h}$ and then sintered at $1100{ }^{\circ} \mathrm{C}$ and $1200{ }^{\circ} \mathrm{C}$ for $5 \mathrm{~h}$. The cubic spinel phase was observed by $\mathrm{XRD}$ analysis in the $\mathrm{NiMn}_{2} \mathrm{O}_{4}$ and $\mathrm{Ni}_{0.5} \mathrm{Co}_{0.8} \mathrm{Mn}_{1.7} \mathrm{O}_{4}$ samples sintered at $1100{ }^{\circ} \mathrm{C}$ for $5 \mathrm{~h}$. The sintering at $1200{ }^{\circ} \mathrm{C}$ resulted in much denser microstructures with a larger grain size. The room-temperature electrical resistivity $\left(\rho_{25}\right)$ and material constant $(B)$ value of the $\mathrm{NiMn}_{2} \mathrm{O}_{4} \mathrm{sample}$ sintered at $1100{ }^{\circ} \mathrm{C}$ were $7710 \Omega \mathrm{cm}$ and $3930 \mathrm{~K}$, respectively. The electrical resistivity of the samples decreased significantly with the addition of $\mathrm{Co}_{3} \mathrm{O}_{4}$. The $\mathrm{B}_{25 / 85}$ values of the $\mathrm{Ni}_{0.5} \mathrm{Co}_{\mathrm{x}} \mathrm{Mn}_{2.5-\mathrm{x}} \mathrm{O}_{4}$ (where $x=0.5,0.8$ and 1.1) samples sintered at $1100{ }^{\circ} \mathrm{C}$ were found to be $3820 \mathrm{~K}, 3525 \mathrm{~K}$ and $3270 \mathrm{~K}$, respectively.

Keywords: cobalt oxide, electrical properties, microstructure, NTC thermistor
\end{abstract}

Preiskovana je bila zgradba in električne lastnosti $\mathrm{NiMn}_{2} \mathrm{O}_{4}$ in $\mathrm{Ni}_{0.5} \mathrm{Co}_{x} \mathrm{Mn}_{2.5-\mathrm{x}} \mathrm{O}_{4}$ (kjer je $x=0,5,0,8$ in 1,1 ) NTC termistorjev Vzorci, pripravljeni po običajni tehniki priprave keramike, so bil kalcinirani $2 \mathrm{~h}$ na $900{ }^{\circ} \mathrm{C}$ in potem $5 \mathrm{~h}$ sintrani na $1100{ }^{\circ} \mathrm{C}$ in $1200{ }^{\circ} \mathrm{C}$. Kubična špinelna faza je bila opažena pri XRD-analizi, v vzorcih $\mathrm{NiMn}_{2} \mathrm{O}_{4}$ in $\mathrm{Ni}_{05} \mathrm{Co}_{0} \mathrm{Mn}_{1.7} \mathrm{O}_{4}$, sintranih $5 \mathrm{~h}$ na $1100{ }^{\circ} \mathrm{C}$ Sintranje na $1200{ }^{\circ} \mathrm{C}$ je povzročilo mnogo bolj gosto mikrostrukturo z večjimi zrni. Vrednosti za električno upornost pri sobni temperaturi $\left(\rho_{25}\right)$ in materialne konstante $(B)$ vzorca $\mathrm{NiMn}_{2} \mathrm{O}_{4}$, sintranega na $1100{ }^{\circ} \mathrm{C}$, sta bili $7710 \Omega \mathrm{cm}$ in $3930 \mathrm{~K}$. Električna upornost vzorcev se je občutno zmanjšala po dodatku $\mathrm{Co}_{3} \mathrm{O}_{4}$. Vrednosti $\mathrm{B}_{25 / 85}$ pri vzorcih $\mathrm{Ni}_{0.5} \mathrm{Co}_{\mathrm{x}} \mathrm{Mn}_{2.5-\mathrm{x}} \mathrm{O}_{4}(\mathrm{kjer}$ je bil $x=0,5$, $0,8$ in 1,1$)$ sintranih na $1100{ }^{\circ} \mathrm{C}$ so bile: $3820 \mathrm{~K}, 3525 \mathrm{~K}$ in $3270 \mathrm{~K}$.

Ključne besede: kobaltov oksid, električne lastnosti, mikrostruktura, NTC termistor

\section{INTRODUCTION}

Sensors for monitoring and controlling temperature are very important, not only in our daily life but also in many industrial and laboratory applications such as aerospace and automotive industries, circuit compensation, cryogenic systems etc. ${ }^{1,2}$ NTC thermistors are useful for precision temperature measurements as their resistance decreases with increasing temperature. ${ }^{3}$ The most extensively used negative temperature coefficient (NTC) thermistor materials are nickel-manganite-based semiconducting materials which exhibit the spinel-type crystal structure with the general formula $\mathrm{AB}_{2} \mathrm{O}_{4} \cdot{ }^{4}$ In the spinel structure, there are two sites available for the cations, i.e., the tetrahedral site, A-site, and the octahedral site, B-site. The distribution of the ions over the sites is as follows: $\mathrm{Mn}^{3+}$ will predominantly occupy the B-site, while $\mathrm{Mn}^{2+}$ will be placed on the A-site and the majority $\mathrm{Ni}^{2+}$ will go to the B-site. ${ }^{5}$ The electrical resistivity, $\rho$, of NTC thermistors varies exponentially with temperature, $T$, by the well-known Arrhenius equation $\rho=\rho_{\mathrm{o}} \exp$ $(B / T)$, where $\rho_{\mathrm{o}}$ is the resistivity of the material at infinite temperature and $B$ is a constant, which is a measure of the sensitivity of the materials over a given temperature. ${ }^{6}$ The material constant $B$, can be calculated using Equation (1):

$$
B_{\frac{T 1}{T 2}}=\frac{\ln \rho_{1}-\ln \rho_{2}}{\frac{1}{T_{1}}-\frac{1}{T_{2}}}
$$

where $\rho_{1}$ and $\rho_{2}$ are the electrical resistivity at temperatures $T_{1}$ and $T_{2}$, respectively. The activation energy $E_{\mathrm{a}}$ can also found by the equation $B=E_{\mathrm{a}} / k_{\mathrm{B}}$, where $k_{\mathrm{B}}$ is the Boltzmann constant. ${ }^{7}$

The electrical properties of nickel-manganite-based NTC thermistors closely depend on the ratio of the compositions (type and amount of additives), initial particle size of raw materials and processing conditions (selected synthesis method, calcination and sintering temperature, sintering time etc.). Attainment of high-density, controlled-grain-size microstructures and appropriate dimensional designs are important factors in good sensor design. ${ }^{8}$ Previous studies have been focused on the effect 
of composition ratios and different production routes on the electrical properties of various metal-oxide-doped NTC thermistors. In this study, nano-sized cobalt-oxideadded, nickel-manganite-based NTC thermistors were fabricated by the solid-state reaction method, the effect of dopant concentration and sintering temperature on the structural and electrical properties of NTC materials were investigated.

\section{EXPERIMENTAL PART}

The particle size of $\mathrm{Co}_{3} \mathrm{O}_{4}$ powder was less than 50 $\mathrm{nm}$, purchased from Sigma-Aldrich. NiO (99\% purity, Alfa Aesar), $\mathrm{Co}_{3} \mathrm{O}_{4}$ (99.5\% purity, Sigma-Aldrich) and $\mathrm{Mn}_{2} \mathrm{O}_{3}$ (99\% purity, Sigma-Aldrich) powders were weighed according to the compositions of $\mathrm{NiMn}_{2} \mathrm{O}_{4}$ and $\mathrm{Ni}_{0.5} \mathrm{Co}_{\mathrm{x}} \mathrm{Mn}_{2.5-\mathrm{x}} \mathrm{O}_{4}$ (where $\mathrm{x}=0.5,0.8$ and 1.1). The molar ratios of these compositions are given in Table $\mathbf{1}$. The raw powder mixture was ball-milled using $\mathrm{ZrO}_{2}$ balls as a grinding media with ethyl alcohol in a jar for $5 \mathrm{~h}$. The obtained slurries were dried and powders were calcinated at $900{ }^{\circ} \mathrm{C}$ for $2 \mathrm{~h}$. The powders were pressed to form disc-shaped specimens and then sintered at 1100 and $1200{ }^{\circ} \mathrm{C}$ for $5 \mathrm{~h}$ employing a $360{ }^{\circ} \mathrm{C} / \mathrm{h}$ heating rate in the air and then cooled naturally in the furnace. The bulk density $\left(\rho, \mathrm{g} \mathrm{cm}^{-3}\right)$ of the sintered samples was calculated from their weights and dimensions. The phases in the sintered samples were determined by X-ray diffraction (XRD, Rigaku D/Max-2200/PC) analysis using $\mathrm{Cu}-\mathrm{K} \alpha$ radiation at $60 \mathrm{kV} / 2 \mathrm{~kW}$.

Table 1: Molar ratio of $\mathrm{Ni}, \mathrm{Mn}$ and $\mathrm{Co}$ in all compositions Tabela 1: Molarno razmerje $\mathrm{Ni}, \mathrm{Mn}$ in $\mathrm{Co} \mathrm{v}$ vseh spojinah

\begin{tabular}{|c|c|c|c|}
\hline $\begin{array}{c}\text { Composition } \\
\text { code }\end{array}$ & $\begin{array}{c}\mathrm{Ni} \\
\text { (moles) }\end{array}$ & $\begin{array}{c}\text { Mn } \\
\text { (moles) }\end{array}$ & $\begin{array}{c}\text { Co } \\
\text { (moles) }\end{array}$ \\
\hline A1 & 1 & 2 & - \\
\hline A2 & 0.5 & 2 & 0.5 \\
\hline A6 & 0.5 & 1.7 & 0.8 \\
\hline A10 & 0.5 & 1.4 & 1.1 \\
\hline
\end{tabular}

In order to calculate the lattice parameter of the samples Equation (2) was applied:

$$
a=d \sqrt{h^{2}+k^{2}+l^{2}}
$$

where $h, k$ and $l$ are the miller indices, $a(\mathrm{~nm})$ is the lattice parameter of cubic structure, $d$ is the interplanar spacing of the peaks corresponding to (311).

The volume of the unit cell $\left(V, \mathrm{~nm}^{3}\right)$ for the cubic system is obtained from Equation (3):

$$
V=a^{3}
$$

The average values of the crystallite size $(D, \mathrm{~nm})$ of the samples were calculated by means of X-ray line broadening method, using the Debye Scherrer formula:

$$
D=\frac{0.9 \lambda}{\beta \cos \theta}
$$

where 0.9 is a constant related to crystallite shape, $\lambda$ is the $\mathrm{X}$-ray radiation wavelength in nanometres $(\mathrm{nm}), \beta$ is the full width at half-maximum (FWHM) of the peaks corresponding to (311) and $\theta$ is Bragg's angle. ${ }^{9}$ The value of $\beta$ from the $2 \theta$ axis of the diffraction profile must be in radians. ${ }^{10}$ The microstructure of the samples was observed using scanning electron microscopy (SEM, JEOL, JSM 5600) on fracture surfaces. The sintered samples were coated with silver paste to form electrodes. The electrical resistance was measured in a temperature programmable furnace between $25{ }^{\circ} \mathrm{C}$ and $85{ }^{\circ} \mathrm{C}$ in steps of $0.1{ }^{\circ} \mathrm{C}$. The material constant, $B$, the activation energy, $E_{\mathrm{a}}$, and the sensitivity coefficient, $\alpha$, values were calculated for the NTC thermistors.

\section{RESULTS}

The XRD patterns of the $\mathrm{NiMn}_{2} \mathrm{O}_{4}$ and $\mathrm{Ni}_{0.5} \mathrm{Co}_{0.8} \mathrm{Mn}_{1.7} \mathrm{O}_{4}$ samples sintered at $1100{ }^{\circ} \mathrm{C}$ for $5 \mathrm{~h}$ are given in Figure 1. The calculated lattice parameter, unit-cell volume, $\beta$, peak position corresponding to (311) and crystallite size of the samples are given in Table 2 . The XRD analysis of these samples demonstrated only the cubic spinel phase (PDF No: 71-0852). A comparison of the XRD patterns of the sintered samples and the data is given in Table 2, the diffraction peaks of the $\mathrm{Ni}_{0.5} \mathrm{Co}_{0.8} \mathrm{Mn}_{1.7} \mathrm{O}_{4}$ sample shifted to higher $2 \theta$ angles, and

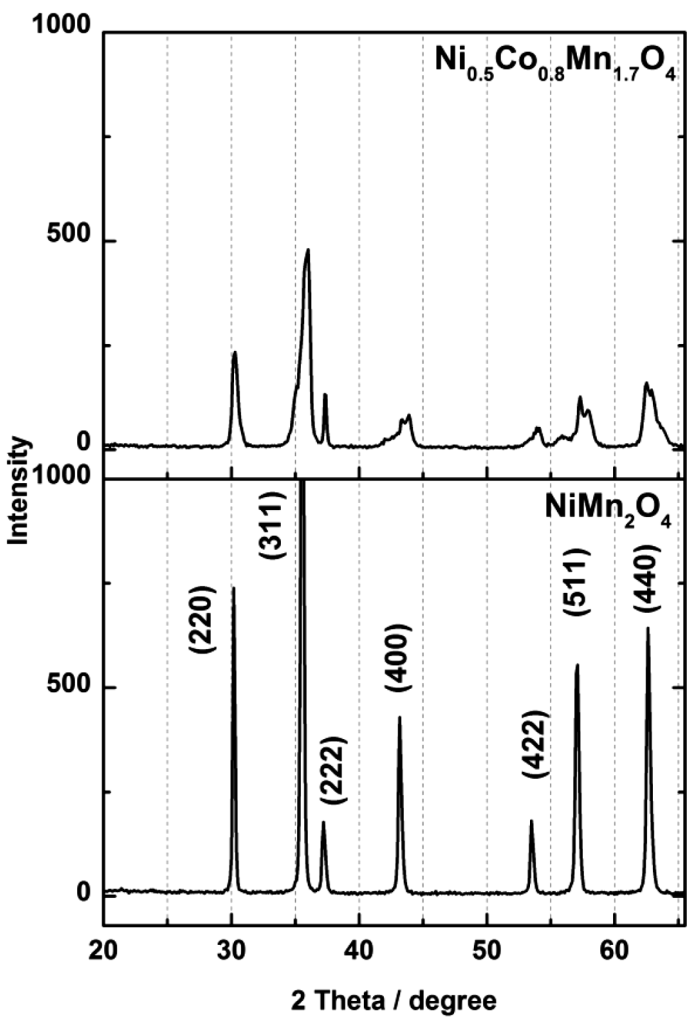

Figure 1: XRD patterns of $\mathrm{NiMn}_{2} \mathrm{O}_{4}$ (A1) and $\mathrm{Ni}_{0.5} \mathrm{Co}_{0.8} \mathrm{Mn}_{1.7} \mathrm{O}_{4}$ (A6) samples in the $2 \theta$ range $20-65^{\circ}$

Slika 1: Rentgenogram vzorcev $\mathrm{NiMn}_{2} \mathrm{O}_{4}$ (A1) in $\mathrm{Ni}_{0.5} \mathrm{Co}_{0.8} \mathrm{Mn}_{1.7} \mathrm{O}_{4}$ (A6) v področju $2 \theta$ med $20^{\circ}$ in $65^{\circ}$ 

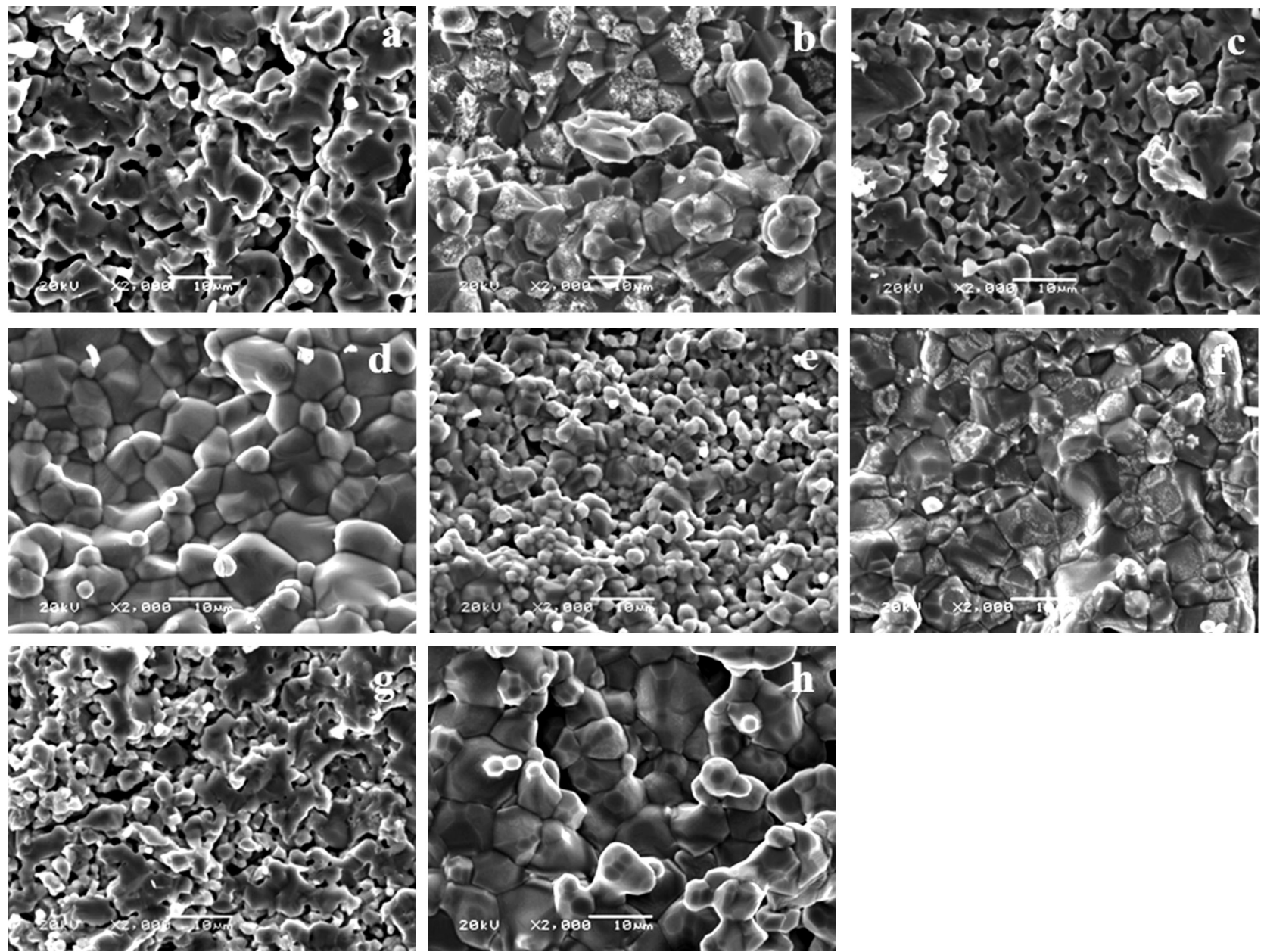

Figure 2: SEM micrographs of sintered samples: A1 a) $1100{ }^{\circ} \mathrm{C}$, b) $\left.1200{ }^{\circ} \mathrm{C}, \mathrm{A} 2 \mathrm{c}\right) 1100{ }^{\circ} \mathrm{C}$, d) $1200{ }^{\circ} \mathrm{C}, \mathrm{A} 6$ e) $1100{ }^{\circ} \mathrm{C}$, f) $\left.1200{ }^{\circ} \mathrm{C}, \mathrm{A} 10 \mathrm{~g}\right) 1100{ }^{\circ} \mathrm{C}$, h) $1200^{\circ} \mathrm{C}$

Slika 2: SEM-posnetki sintranih vzorcev: A1 a) $1100{ }^{\circ} \mathrm{C}$, b) $1200{ }^{\circ} \mathrm{C}$, A2 c) $1100{ }^{\circ} \mathrm{C}$, d) $1200{ }^{\circ} \mathrm{C}, \mathrm{A} 6$ e) $1100{ }^{\circ} \mathrm{C}$, f) $\left.\left.1200{ }^{\circ} \mathrm{C}, \mathrm{A} 10 \mathrm{~g}\right) 1100{ }^{\circ} \mathrm{C}, \mathrm{h}\right)$ $1200{ }^{\circ} \mathrm{C}$

as a result the lattice parameters and the unit-cell volume decreased. The value of $\beta$ increased to $0.7692^{\circ}$ and the value of average crystallite size decreased to $10.86 \mathrm{~nm}$.

Table 2: The lattice parameter, unit-cell volume, $\beta$, peak position and crystallite size of samples sintered at $1100{ }^{\circ} \mathrm{C}$

Tabela 2: Parameter mreže, prostornina enotne celice, $\beta$, položaj vrhov in velikost kristalnih zrn vzorcev sintranih na $1100{ }^{\circ} \mathrm{C}$

\begin{tabular}{|c|c|c|c|c|c|}
\hline Composition & $\begin{array}{c}a \\
(\mathrm{~L})\end{array}$ & $\begin{array}{c}V \\
\left(\mathrm{~L}^{3}\right)\end{array}$ & $\begin{array}{c}\beta \\
(311) \\
\left({ }^{\circ}\right)\end{array}$ & $\begin{array}{c}2 \theta \\
(311) \\
\left({ }^{\circ}\right)\end{array}$ & $\begin{array}{c}D \\
(\mathrm{~nm})\end{array}$ \\
\hline $\mathrm{NiMn}_{2} \mathrm{O}_{4}(\mathrm{~A} 1)$ & 0.8365 & 0.585 & 0.2538 & 35.6 & 32.87 \\
\hline $\mathrm{Ni}_{0.5} \mathrm{Co}_{0.8} \mathrm{Mn}_{1.7} \mathrm{O}_{4}(\mathrm{~A} 6)$ & 0.8273 & 0.566 & 0.7692 & 36 & 10.86 \\
\hline
\end{tabular}

The bulk densities of the sintered $\mathrm{NiMn}_{2} \mathrm{O}_{4}$ and $\mathrm{Ni}_{0.5} \mathrm{Co}_{\mathrm{x}} \mathrm{Mn}_{2.5-\mathrm{x}} \mathrm{O}_{4}$ samples are shown in Table 3. The bulk density of the A1 sample sintered at $1100{ }^{\circ} \mathrm{C}$ was found to be $4.23 \mathrm{~g} \mathrm{~cm}^{-3}$ and it increased to $4.78 \mathrm{~g} \mathrm{~cm}^{-3}$ when the sample was sintered at $1200{ }^{\circ} \mathrm{C}$. The bulk density of the samples decreased first and then increased with the addition of $\mathrm{Co}_{3} \mathrm{O}_{4}$.
Table 3: The bulk density of samples sintered at $1100{ }^{\circ} \mathrm{C}$ and $1200{ }^{\circ} \mathrm{C}$ for $5 \mathrm{~h}$

Tabela 3: Gostota osnove po 5 urnem sintranju na $1100{ }^{\circ} \mathrm{C}$ in $1200{ }^{\circ} \mathrm{C}$

\begin{tabular}{|c|c|c|}
\hline \multirow{2}{*}{ Composition code } & \multicolumn{2}{|c|}{$\rho\left(\mathrm{g} \mathrm{cm}^{-3}\right)$} \\
\cline { 2 - 3 } & $1100{ }^{\circ} \mathrm{C}$ & $1200{ }^{\circ} \mathrm{C}$ \\
\hline A1 & 4.23 & 4.78 \\
\hline A2 & 4.05 & 4.43 \\
\hline A6 & 4.27 & 4.63 \\
\hline A10 & 4.30 & 4.72 \\
\hline
\end{tabular}

The SEM micrographs of the A1, A2, A6, A10 samples sintered at 1100 and $1200{ }^{\circ} \mathrm{C}$ for $5 \mathrm{~h}$ are given in Figure 2. It can be seen in this figure that all the samples sintered at $1100{ }^{\circ} \mathrm{C}$ had a fine-grained microstructure with most of the pores at the grain boundaries. The grain size of A1 was larger relative to the A2, A6 and A10 samples sintered at $1100{ }^{\circ} \mathrm{C}$. When the sintering temperature was increased to $1200{ }^{\circ} \mathrm{C}$, all the samples had a much denser microstructure and larger grains with a number of small grains on their surface. In addition, 

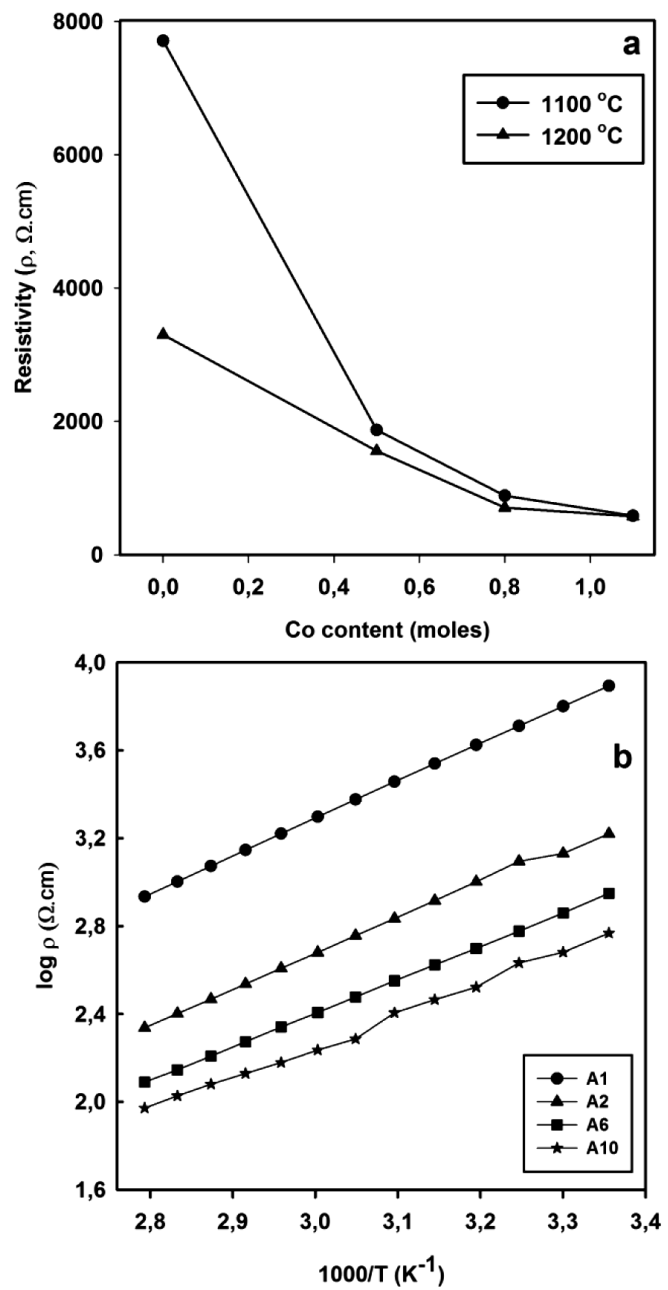

Figure 3: a) The change of resistivity as a function of cobalt content b) the relationship between $\log \rho$ and $1000 / T\left(\mathrm{~K}^{-1}\right)$ for A1, A2, A6 and A10 samples

Slika 3: a) Sprememba upornosti v odvisnosti od vsebnosti kobalta, b) odvisnost med $\log \rho$ in $1000 / T\left(\mathrm{~K}^{-1}\right)$ pri vzorcih A1, A2, A6 in A10

the A10 sample had much bigger grains in comparison with the A2 and A6 samples sintered at $1200{ }^{\circ} \mathrm{C}$.

The plot of resistivity versus Co content (moles) and the plots of $\log \rho$ versus 1000/T are given in Figures 3a and $\mathbf{3 b}$ for all the sintered samples. The plots of $\log \rho$ versus 1000/T exhibited a linear dependence in the range $25-85{ }^{\circ} \mathrm{C}$, indicating semiconducting NTC thermistor characteristics. The activation energy, the sensitivity coefficient and the material constant can also be calculated from this plot. The room-temperature electrical resistances, $R_{25}$, of the $\mathrm{A} 1, \mathrm{~A} 2, \mathrm{~A} 6$ and $\mathrm{A} 10$ samples sintered at $1100{ }^{\circ} \mathrm{C}$ were $1487,360,167$ and $107 \Omega$, respectively. For the same sintering temperature, the room temperature electrical resistivity of the A1, A2, A6 and A10 samples were calculated as 7710, 1870, 890 and $590 \Omega \mathrm{cm}$, respectively.

The relationship between the $B_{25 / 85}$ constant of the samples and the increase in $\mathrm{Co}_{3} \mathrm{O}_{4}$ content is given in Figure 4. The activation energy and sensitivity coefficient value of the samples is given in Table 4 . With in-

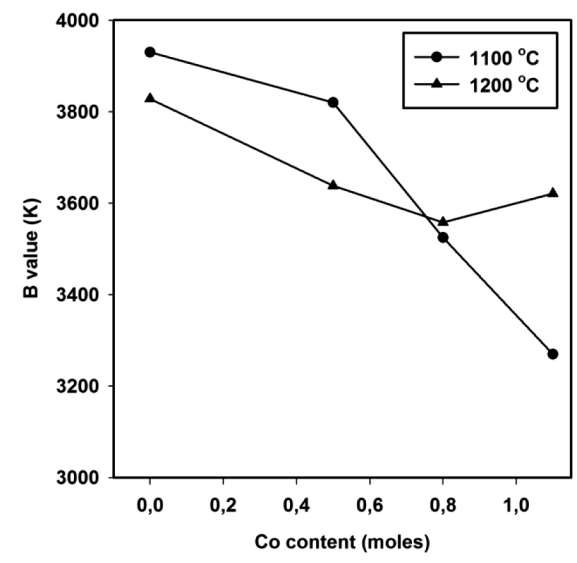

Figure 4: Effect of cobalt content on $B_{25 / 85}$ value of A1, A2, A6 and A10 samples sintered at 1100 and $1200{ }^{\circ} \mathrm{C}$

Slika 4: Vpliv vsebnosti kobalta na vrednost $B_{25 / 85}$ vzorcev A1, A2, A6 in $\mathrm{A} 10$, sintranih na $1100{ }^{\circ} \mathrm{C}$ in na $1200{ }^{\circ} \mathrm{C}$

creasing Co content, the $B_{25 / 85}$ constant and activation energy of the samples sintered at $1100{ }^{\circ} \mathrm{C}$ decreased from $3930 \mathrm{~K}$ to $3270 \mathrm{~K}$ and from 0.338 to $0.282 \mathrm{eV}$, respectively. A similar tendency was also seen in the A1, A2 and A6 samples sintered at $1200{ }^{\circ} \mathrm{C}$. For the A10 sample, the $B_{25 / 85}$ constant and activation energy values were found to be $3620 \mathrm{~K}$ and $0.312 \mathrm{eV}$, respectively. The sensitivity coefficient value of all samples sintered at $1100{ }^{\circ} \mathrm{C}$ decreased from -4.426 to $-3.683 \% / \mathrm{K}$. When the sintering temperature increased to $1200{ }^{\circ} \mathrm{C}$, the sensitivity coefficient value of all samples decreased from -4.311 to $-4.078 \% / \mathrm{K}$.

Table 4: The activation energy and sensitivity coefficient of A1, A2, A6 and A10 samples sintered at $1100{ }^{\circ} \mathrm{C}$ and $1200^{\circ} \mathrm{C}$ for $5 \mathrm{~h}$

Tabela 4: Aktivacijska energija in koeficient občutljivosti A1, A2, A6 in A10 vzorcev, sintranih 5 ur na $1100{ }^{\circ} \mathrm{C}$ in $1200{ }^{\circ} \mathrm{C}$

\begin{tabular}{|c|c|c|c|c|}
\hline \multirow{2}{*}{$\begin{array}{c}\text { Composition } \\
\text { code }\end{array}$} & \multicolumn{2}{|c|}{$\mathrm{E}_{\mathrm{a}}(\mathrm{eV})$} & \multicolumn{2}{c|}{$\alpha_{25}(\% / \mathrm{K})$} \\
\cline { 2 - 5 } & $1100^{\circ} \mathrm{C}$ & $1200{ }^{\circ} \mathrm{C}$ & $1100^{\circ} \mathrm{C}$ & $1200{ }^{\circ} \mathrm{C}$ \\
\hline $\mathrm{A} 1$ & 0.338 & 0.330 & -4.426 & -4.311 \\
\hline $\mathrm{A} 2$ & 0.329 & 0.313 & -4.301 & -4.097 \\
\hline $\mathrm{A} 6$ & 0.303 & 0.306 & -3.970 & -4.007 \\
\hline $\mathrm{A} 10$ & 0.282 & 0.312 & -3.683 & -4.078 \\
\hline
\end{tabular}

\section{DISCUSSION}

The cubic spinel phase was found by XRD analysis in $\mathrm{NiMn}_{2} \mathrm{O}_{4}$ and $\mathrm{Ni}_{0.5} \mathrm{Co}_{0.8} \mathrm{Mn}_{1.7} \mathrm{O}_{4}$ samples sintered at $1100{ }^{\circ} \mathrm{C}$ for $5 \mathrm{~h}$. No secondary phase was found in these samples. As it is well known from the binary phase diagram of Mn-Ni-O, the spinel phase can only form when the ratio of $\mathrm{Ni} /(\mathrm{Ni}+\mathrm{Mn})$ is less than 0.35 at a calcination temperature of $900{ }^{\circ} \mathrm{C} .1^{11}$ The diffraction peaks of $\mathrm{Ni}_{0.5} \mathrm{Co}_{0.8} \mathrm{Mn}_{1.7} \mathrm{O}_{4}$ samples shift to the higher $2 \theta$ angles, indicating a decrease in the lattice parameter with the addition of $\mathrm{Co}_{3} \mathrm{O}_{4}$ due to the differences between the ionic radii of the $\mathrm{Mn}$ and $\mathrm{Co}$ ions. Wu et al. ${ }^{12}$ reported that the peak shift toward higher $2 \theta$ angles with the increasing of Co content indicates lattice constriction when 
Co substitutes Mn. It was also reported that the decrease in the lattice parameter with the addition of Co should be attributed to the fact that the ionic radius of $\mathrm{Co}^{2+}$ $(0.072 \mathrm{~nm})$ is smaller than that of $\mathrm{Mn}^{2+}(0.080 \mathrm{~nm})$ for occupying the tetrahedral sites and/or $\mathrm{Co}^{3+}(0.068 \mathrm{~nm})$ is smaller than $\mathrm{Mn}^{3+}(0.072 \mathrm{~nm})$ for occupying the octahedral sites. ${ }^{12,13}$ As can be seen in Figure 1, we observed a significant broadening and a decrease of the diffraction peak intensities in the XRD pattern of the $\mathrm{Ni}_{0.5} \mathrm{Co}_{0.8} \mathrm{Mn}_{1.7} \mathrm{O}_{4}$ sample. This could be attributed to a decrease in the average crystallite size as given in Table 2 due to the nano-size of the $\mathrm{Co}_{3} \mathrm{O}_{4}$ starting powder. Savic et al. reported that the increase in the diffraction peak width and the decrease in the peak intensities in the XRD patterns are associated with a decreasing of the crystallite size and an increasing of the strain. ${ }^{14}$

Since the desired NTC thermistor properties strongly depend on the densification and grain size, we also investigated the microstructure properties of these samples. The bulk density and grain size of the A1, A2, A6 and A10 samples sintered at $1100{ }^{\circ} \mathrm{C}$ were less than the samples sintered at $1200{ }^{\circ} \mathrm{C}$. Smaller grains result in a large number of grain boundaries, which act as scattering centres for the flow of electrons and therefore higher electrical resistivity values were obtained when the samples were sintered at $1100{ }^{\circ} \mathrm{C} .{ }^{15}$ As expected, the increasing of the sintering temperature gave rise to an increase in the bulk density and the grain size of these samples, thus the room-temperature resistivity of the samples decreased. In addition, the cation distribution in the octahedral and tetrahedral sites changes with an increasing sintering temperature in the spinel ceramics. The ratio of $\mathrm{Mn}^{3+} / \mathrm{Mn}^{4+}$ in the octahedral sites increases with the increasing sintering temperature and also results in a decrease in the resistivity. ${ }^{16}$ The electrical resistivity of the samples decreased significantly with the increasing of the $\mathrm{Co}_{3} \mathrm{O}_{4}$ content. Muralidharan et al. observed that the resistivity and B-value decreased with the increasing Co content. Their observation is expected as the $\mathrm{Co}^{2+}$ and $\mathrm{Co}^{3+}$ ions can also occupy the octahedral sites and contribute to the electrical conductivity along with $\mathrm{Mn}^{3+} / \mathrm{Mn}^{4+}$ ion pairs in the octahedral sites. This gives rise to a decrease of the resistivity, B-value and temperature coefficient of resistance. ${ }^{2}$ This phenomenon is prominent for all samples sintered at $1100{ }^{\circ} \mathrm{C}$, while the Co content was increasing in the samples. Similar trends were also observed for the A1, A2 and A6 compositions when the samples were sintered at $1200{ }^{\circ} \mathrm{C}$. When the sintering temperature was increased from 1100 to $1200{ }^{\circ} \mathrm{C}$ for the A10 sample, similar resistivity values were found, but the B-values and activation energy of samples were nearly constant. Moreover, the lattice parameters were found to be $0.8365 \mathrm{~nm}$ and $0.8273 \mathrm{~nm}$ for the $\mathrm{NiMn}_{2} \mathrm{O}_{4}$ and $\mathrm{Ni}_{0.5} \mathrm{Co}_{0.8} \mathrm{Mn}_{1.7} \mathrm{O}_{4}$ samples, respectively. This may be due to the fact that the hopping distance of the charge carriers becomes easier with the decreasing lattice parameter, thus the resistivity value decreases. ${ }^{17}$ The sensitivity coefficient and the activation-energy values of all the samples were found in the range -4.426 to $-3.683 \% / \mathrm{K}$ and $0.282 \mathrm{eV}$ to $0.338 \mathrm{eV}$, respectively. It is well known that the desired sensitivity coefficient, $\alpha_{25}$, and the activation energy of the NTC thermistors are in the range $-2.2 \% / \mathrm{K}$ to $-5.5 \% / \mathrm{K}$ and $0.1-1.5 \mathrm{eV}$, respectively. ${ }^{18,19}$

\section{CONCLUSION}

The influence of nano-sized cobalt oxide additions on the structural and electrical properties of nickel-manganite-based NTC thermistors was investigated. Our results in this work indicate that a wide range of electrical properties of nickel-manganite-based NTC thermistors can be obtained by the addition of nano-sized cobalt oxide. The particularly interesting finding in this study demonstrated that the $\mathrm{Ni}_{0.5} \mathrm{Co}_{1.1} \mathrm{Mn}_{1.4} \mathrm{O}$ sample sintered at $1200{ }^{\circ} \mathrm{C}$ for $5 \mathrm{~h}$ has a low electrical resistivity and a high $B$-constant.

\section{Acknowledgements}

This study is supported by TÜBİTAK (The Scientific and Technical Research Council of Turkey), Project number 3001-114M860. We would like to thank TÜBİTAK for its financial support.

\section{REFERENCES}

${ }^{1}$ R. N. Jadhav, S. N. Mathad, V. Puri, Studies on the properties of $\mathrm{Ni}_{0.6} \mathrm{Cu}_{0.4} \mathrm{Mn}_{2} \mathrm{O}_{4}$ NTC ceramic due to $\mathrm{Fe}$ doping, Ceramics International, 38 (2012), 5181-5188, doi:10.1016/j.ceramint.2012. 03.024

${ }^{2}$ M. N. Muralidharan, P. R. Rohini, E. K. Sunny, K. R. Dayas, A. Seema, Effect of $\mathrm{Cu}$ and $\mathrm{Fe}$ addition on electrical properties of $\mathrm{Ni}-\mathrm{Mn}-\mathrm{Co}-\mathrm{O}$ NTC thermistor compositions, Ceramics International, 38 (2012), 6481-6486, doi:10.1016/j.ceramint.2012. 05.025

${ }^{3}$ J. Fraden, Handbook of Modern Sensors Physics, Designs, and Applications, Springer Science+Business Media, New York 2010

${ }^{4}$ E. D. Macklen, Thermistors, Electrochemical Publications Limited, Scotland 1979

${ }^{5}$ K. Park, Fabrication and Electrical Properties of Mn-Ni-Co-Cu-Si Oxides Negative Temperature Coefficient Thermistors, Journal of the American Ceramic Society, 88 (2005), 862-866, doi:10.1111/ j.1551-2916.2005.00170.x

${ }^{6}$ J. Wang, J. Zhang, Effects of Mg substitution on microstructure and electrical properties of $\mathrm{NiMn}_{2-\mathrm{x}} \mathrm{Mg}_{\mathrm{x}} \mathrm{O}_{4}$ NTC ceramics, Journal of Materials Research, 27 (2012), 928-931, doi:10.1557/jmr.2012.29

${ }^{7}$ K. Park, S. J. Kim, J. G. Kim, S. Nahm, Structural and electrical properties of MgO-doped $\mathrm{Mn}_{1.4} \mathrm{Ni}_{1.2} \mathrm{Co}_{0.4-\mathrm{x}} \mathrm{Mg}_{\mathrm{x}} \mathrm{O}_{4}(0=\mathrm{x}=0.25) \mathrm{NTC}$ thermistors, Journal of the European Ceramic Society, 27 (2007), 2009-2016, doi:10.1016/j.jeurceramsoc.2006.07.002

${ }^{8}$ M. Hosseini, B. Yasaei, Effect of Grain Size and Microstructures on Resistivity of Mn-Co-Ni Thermistor, Ceramics International, 24 (1998), 543-545

${ }^{9}$ S. Talam, S. R. Karumuri, N. Gunnam, Synthesis, Characterization, and Spectroscopic Properties of ZnO Nanoparticles, ISRN Nanotechnology, 2012 (2012) 372505, 1-6, doi:10.5402/2012/372505

${ }^{10}$ A. Monshi, M. R. Foroughi., M. R. Monshi, Modified Scherrer Equation to Estimate More Accurately Nano-Crystallite Size Using XRD, World Journal of Nano Science and Engineering, 2 (2012), 154-160, doi:10.4236/wjnse.2012.23020 
${ }^{11}$ M. N. Muralidharan, E. K. Sunny, K. R. Dayas, A. Seema, K. R. Resmi, Optimization of process parameters for the production of $\mathrm{Ni}-\mathrm{Mn}-\mathrm{Co}-\mathrm{Fe}$ based NTC chip thermistors through tape casting route, Journal of Alloys and Compounds, 509 (2011), 9363-9371, doi:10.1016/j.jallcom.2011.07.037

${ }^{12}$ J. Wu, Z. Huang, Y. Hou, Y. Gao, J. Chu, Structural, electrical, and magnetic properties of $\mathrm{Mn}_{2.52}{ }_{-} \mathrm{Co}_{\mathrm{x}} \mathrm{Ni}_{0.48} \mathrm{O}_{4}$ films, Journal of Applied Physics, 107 (2010) 053716, 1-6, doi:10.1063/1.3309780

${ }^{13}$ R. D. Shannon, Revised Effective Ionic Radii and Systematic Studies of Interatomic Distances in Halides and Chalcogenides, Acta Crystallography, A32 (1976), 751-767

${ }^{14}$ S. M. Savic, L. Mancic, K. Vojisavljevic, G. Stojanovic, Z. Brankovic, O. S. Aleksic, G. Brankovic, Microstructural and electrical changes in nickel manganite powder induced by mechanical activation, Materials Research Bulletin, 46 (2011), 1065-1071, doi:10.1016/j.materresbull.2011.03.008

${ }^{15} \mathrm{~S}$. A. Kanade, V. Puri, Electrical properties of thick-film NTC thermistor composed of $\mathrm{Ni}_{0.8} \mathrm{Co}_{0.2} \mathrm{Mn}_{2} \mathrm{O}_{4}$ ceramic: Effect of inorganic oxide binder, Materials Research Bulletin, 43 (2008), 819-824, doi:10.1016/j.materresbull.2007.05.008
${ }^{16}$ W. Kong, L. Chen, B. Gao, B. Zhang, P. Zhao, G. Ji, A. Chang, C. Jiang, Fabrication and properties of $\mathrm{Mn}_{1.56} \mathrm{Co}_{0.96} \mathrm{Ni}_{0.48} \mathrm{O}_{4}$ free-standing ultrathin chips, Ceramics International, 40 (2014), 8405-8409, doi:10.1016/j.ceramint.2014.01.049

${ }^{17}$ C. Ma, Y. Liu, Y. Lu, H. Gao, H. Qian, J. Ding, Preparation and characterization of $\mathrm{Ni}_{0.6} \mathrm{Mn}_{2.4} \mathrm{O}_{4}$ NTC ceramics by solid-state coordination reaction, Journal of Materials Science: Materials in Electronics, 24 (2013), 5183-5188, doi:10.1007/s10854-013-1542-2

${ }^{18}$ A. Feteira, Negative Temperature Coefficient Resistance (NTCR) Ceramic Thermistors: An Industrial Perspective, Journal of the American Ceramic Society, 92 (2009), 967-983, doi:10.1111/j.15512916.2009.02990.x

${ }^{19}$ K. Park, I. H. Han, Effect of $\mathrm{Cr}_{2} \mathrm{O}_{3}$ addition on the microstructure and electrical properties of Mn-Ni-Co oxides NTC thermistors, Journal of Electroceramics, 17 (2006), 1069-1073, doi:10.1007/s10832006-8317-6 